\title{
Urbanism as a Chinese Way of Life
}

\author{
MARTIN KING WHYTE \\ University of Michigan, Ann Arbor, MI, U.S.A.
}

\begin{abstract}
$\mathrm{T}$ WO GENERATIONS have passed since Louis Wirth (1938) published his influential and controversial piece, "Urbanism as a Way of Life," which attempted to specify the universal features of urban places. Since then his effort has often been criticized, yet the question of whether there are universals of urbanism continues to fascinate urban sociologists (see, for example, Duncan 1957; Dewey 1960; Fischer 1976). In recent years the revival of interest in Marxism among Western social scientists has led to a modified thesis gaining some currency: features of urbanism such as those identified by Wirth are inherent consequences of capitalism, but could be avoided in some socialist cities (Castells 1977; Smith 1979). Also in recent years there has been a flurry of interest in urban organization in the People's Republic of China and some suggestions that the Chinese Communists had, in fact, managed to establish a new form of city life that avoided most "evils of urbanism." (see Sidel 1974; Cell 1979) We propose to consider here the Chinese case in a comparative context in order to assess these various arguments. ${ }^{1}$

When the Chinese Communists rode their rural revolution to power in 1949 they held a jaundiced view of the nature of the cities that fell to their armies. The list of "evils" used in characterizing Chinese cities resembles the negative side of urbanism portrayed by Louis Wirth and by neo-Marxists today. (Murphey 1980; Meisner 1974) To the Chinese Communists, cities were strongholds of capitalism, private property, and market relationships. Formal extraterritoriality had ended in 1943, but foreign ownership and influence were substantial, including foreign textile and match factories, missionary-run schools and the YMCA, and foreign styles of dress and American movies. Poverty and unemployment were rampant, as the squatter settlements and the carts that picked up dead bodies off the street each morning gave vivid testimony. At the other end of the scale, urban elites engaged in conspicuous consumption on a grand scale, and their offspring dominated the better schools and jobs in the modern sector. Runaway inflation and the absence of job security added to the insecurities of the urban populace. Within cities social problems abounded, with crime, drug addiction, prostitution, gambling, begging and other phenomena perceived as social cancers by the Chinese Com-
\end{abstract}


munists. Urban areas were perceived as characterized by impersonality, dominance of the cash nexus, alienation, and acceptance of amoral competition for wealth or simply for survival - in Chinese parlance it was not a "dog eat dog world" but a "man eat man world."

When Mao Zedong launched his revolution from the caves of Yanan he had not, so far as we can tell, had the pleasure of reading Louis Wirth. Even if he had had that pleasure we can assume that he would have joined Wirth's critics, for revolutionaries do not like to be told that some things are universals that cannot be changed. Mao and his colleagues developed a Marxist analysis of urban problems and then, after 1949, found themselves in a position to put their beliefs into practice. They set out to systematically reform the nature of urban institutions in China with a view to eliminating those evils that had their roots in capitalism and foreign influence. Many of the changes took place during the 1950s, but it was not until the Cultural Revolution decade (1966-1976) that this "Maoist model of urbanism" took its fullest form. Many of the reforms introduced were similar to those implemented in the Soviet Union and Eastern Europe, but others, particularly in this latter period, were more distinctive. In the following pages I will focus on the mid-1970s and analyze the institutional changes that had been made and their social consequences. Where appropriate, comparisons with other countries, especially the socialist countries of Eastern Europe, will be introduced.

\section{Official Ideals and Institutional Changes}

The Chinese Communist elites had a number of general ideals that guided their thinking about urban transformation. They wanted their cities to be spartan, productive, stable, solidary, tightly organized, and egalitarian. They felt that such an environment would make urbanites feel secure, well provided for, and involved, and that they would express their feelings through diligent work, active political participation, and vigilance against crime, abuses of power, and other forms of behaviour that were officially disapproved.

In their efforts to realize these ideals a wide variety of reforms was introduced. Through negotiation or outright confiscation foreign ownership and control were reduced to minimal levels by 1952. The Korean War provided an opportunity to gain state control over all foreign trade, ban Hollywood movies, and mount campaigns criticizing Western cultural influence in general, although up until 1960, when the Sino-Soviet split occurred, Soviet cultural influence served as partial replacement. By the period we are concerned with, then, there was very little foreign influence evident in Chinese urban life.

The most prominent institutional change carried out during the 1950 s was the transition to socialist property relations. As they came to power the Chinese Communists seized control of major factories, banks, public utilities, and so forth, but for a period privately owned factories and shops were allowed to continue to operate. But a series of political campaigns and administrative regulations removed much of the autonomy of such enterprises, and in 1955-7 the 
private sector was almost totally eliminated, with only a small number of peddlers and roving repairmen remaining outside of the socialist sector. By the late 1950s capitalism had been essentially eliminated from urban China.

The Chinese Communists were not so naive as to believe that simply eliminating foreign influence and capitalist ownership would automatically produce the new forms of urbanism they aspired to. They recognized that other changes were needed and proceeded to carry them out. One of the most important, and distinctive, was the set of migration controls that came fully into force in about 1959. (Tien 1973) These restrictions essentially make it illegal for anyone in the countryside to take up residence in any urban place unless specifically given permission to do so (e.g., as a result of labor recruitment or university enrollment). In addition, no person living in any urban place is supposed to relocate in another urban place without specific approval. (Approval to move to a smaller urban place is fairly easy to come by, but to a larger city is extremely difficult. Even marriage to someone from a larger city does not entitle you to establish a joint residence there.) These migration restrictions are connected to a system of household registration enforced throughout the nation, and valid registration in a locality is required to gain access to most urban resources and opportunities (see below).

Of course, household registration systems are common in many countries, and in the Soviet Union and some Eastern European countries there have been efforts to ban migration into certain large cities. What is distinctive about the Chinese version is the attempt to use household registration not simply to keep track of people, but to keep people at all levels from engaging in individually initiated mobility, even into a rural town of only 10,000 people. Also distinctive is the fact that urban registration is not regarded as a right but as a privilege, and that this privilege can be lost. This has happened on repeated occasions as various sectors of the urban population have been "mobilized" to resettle in the countryside, the most famous instance being the 17 million urban graduates who were rusticated in the decade after 1968 (Bernstein 1977).

An additional set of measures was implemented in the effort to develop a highly penetrating, grass-roots organizational system in urban China. Two complementary systems were involved, one organized around territorial units, the other around production units. In the former, each city is divided into districts, and each district into neighborhoods or wards. At this level of the hierarchy are located the ward government office and ward police station whose salaried professionals supervise the lower levels of the hierarchy. Each ward is, in turn, divided into residents' committees which supervise 100-800 households, often those living on a city block or in several apartment buildings. These are, in turn, divided into residents' small groups supervising 15-40 households, generally those living along a lane or in a single building. These are not voluntary community associations but organizations mandated by law in 1954 (see Cohen 1968, Chap. 2), and the leaders of these lowest two levels are local residents who are appointed or elected in "guided" elections run by ward officials. 
These neighborhood organizations have a wide variety of roles they are supposed to play, both providing services and insuring social control. The ward may run workshops, nursery schools, bicycle repair shops and other small facilities, and they carry out innoculations against diseases, organize residents to sweep lanes and alleys, and may set up a reading room for retired people and deliver coal to the infirm. In terms of social control the residents' committees and small groups organize local people for political study meetings of official propaganda, they may organize residents for night-time guard duty and patrols of the neighborhood, they seasonally check each household for cleanliness, and they are expected to alert the ward police to suspicious comings and goings in the neighborhood, leading to surprise night-time searches of homes. In general when the authorities want to enforce any new policy, whether it be the campaign to send urban school graduates to the countryside or to restrict urban families to having only one child, the authorities mobilize this network to convene meetings, carry out visits to individual homes, and otherwise pressure for universal compliance.

The work organization half of this administrative system has similar roles to play. Work enterprises of course organize the daily routine of work, but they also have many other functions. They organize their employees for after hours political study meetings, local security patrols, cleanliness inspections, birth control meetings, and so forth. Employees who commute to work fall under the supervision of both neighborhood and work unit systems, but in large enterprises which provide housing, nursery schools, clinics and other facilities on the premises, employees fall solely under the supervision of their employing unit. Such cases bring to mind some parallels from other societies - an American company town, the English "new towns," or a Japanese high technology company. But the intrusiveness and inclusiveness of controls in the Chinese work unit are arguably greater than in any of these cases from capitalist societies and even in comparison with production enterprises in socialist Eastern Europe (see Bater 1980; French and Hamilton 1979). Not only are attempts made to preempt spontaneous associational life, but very personal decisions - whether to marry, to have another baby, or to get divorced, for example - have first to be referred to one's work unit superiors for approval.

An additional set of institutional changes involved the effort to restrict market forces and relationships to a substantial extent and substitute direct bureaucratic allocation. In terms of employment, there was an effort to develop a work assignment system and eliminate any sort of labor market. Labor bureaus were established in cities and empowered to assign individuals leaving school to jobs, and individuals were obliged to accept these jobs and remain working at them unless they were transferred, even if the work did not suit their preferences and skills. This system promoted a Chinese version of permanent employment, or in terms of the local slang, "an iron rice bowl." Employees could expect that if they did not commit a serious crime or political error they would not be laid off or fired, and even if they were transferred they could expect comparable pay and benefits (Korzec and Whyte 1981). But an 
individual who cannot stand his job, has conflicts with his superiors, or feels more suited to other work cannot simply quit and seek other employment, since other enterprises are not supposed to hire people "off the street," but only through labor bureau allocations. ${ }^{2}$ An employee can request a transfer or scarch for an individual elsewhere he can "swap" jobs with, but such individually initiated changes are so difficult to pull off that those who succeed in doing so are looked upon as quite extraordinary. No East European socialist country has attempted to limit the labor market to anything like this iegree, although from 1940 to 1956 the Soviet Union did try to make job changes illegal. As a consequence of this difference, phenomena such as high wage differentials to attract workers to barren regions or difficult jobs and high labor turnover are much more a feature of employment in socialist Eastern Europe than in China.

Most housing is also bureaucratically allocated, at least in the largest cities. In places like Peking and Shanghai there is a small share of private housing left, generally under $10 \%$ of all housing space, but there appears to be little market in such housing, which is mainly passed down and used within particular families. In large cities the bulk of housing is owned and controlled through the two administrative systems already described - work units and neighborhoods. So those in need of new or altered housing have to apply to either their work unit or to district housing management offices for space. There they have to satisfy particular bureaucratic criteria to qualify for housing, and those who qualify generally go on a waiting list. There they may remain for several years until space becomes available, with no private housing market or access to building supplies to build their own home that could give them an alternative. Here the Chinese case is generally similar to Eastern Europe, although in many countries in the latter area it is more possible to finance home construction individually or to subscribe to cooperative apartment construction projects.

Even in food and consumer goods the role of the market has been minimized in urban China. This has occurred through a very extensive system of rationing. Many of the essentials of life require ration coupons or booklets of various kinds in addition to cash, although the list has varied somewhat over time and from city to city. Some of the things always or usually rationed are rice, flour, cooking oil, cotton cloth, some synthetic fabrics, pork, eggs, fish, sugar, powdered milk, beancurd, peanuts, some brands of cigarettes, coal, soap, light bulbs, leather shoes, wristwatches, bicycles, sewing machines, television sets, and major items of furniture (see White 1977). Some items, to be sure, are not usually rationed - fresh vegetables, fruits, toys, dishes, for example - but still the list is so extensive as to make it difficult to live in a city unless one has the necessary ration coupons, which require at least a valid urban registration and often other criteria as well. In the 1950 s some remaining roving peddlers and "free markets" in cities where peasants could come to market extra produce did provide alternatives to reliance on state stores and rationed goods, but during the Cultural Revolution efforts were made to stamp 
out these "remnants of capitalism," resulting in nearly total dependence on the official rationing and supply system.

Rationing is not unknown in other societies, but it has been a more permanent and pervasive part of the Chinese system. In Eastern Europe and the Soviet Union, for example, rationing has generally been employed to cope with temporary shortages of particular items and has been replaced by market distribution (although at fixed state prices) as soon as supplies permitted. In China some items, like grain products, continue to be rationed even when the public generally perceives they are not in short supply, which suggests that other goals of rationing besides coping with shortages are paramount in the Chinese case - for example, restricting migration to the city, and preventing unequal consumption within the city.

The emphasis on bureaucratic allocation is extended to other areas as well in China. Health care, for example, is subject to a bureaucratic allocation system, with no private medical care available and with individuals required to go through the referral system attached to the work unit or neighborhood to which they belong. Schooling worked similarly in these years, with no exambased competition for placement in the highest quality schools, but instead movement up through assigned schools on the basis of administrative recommendations. In general the extreme emphasis on bureaucratic allocation combined with the efforts to stamp out the remnants of private property and market trade that occurred in the Cultural Revolution decade created a system of direct allocation by paternalistic state authorities that is quite distinctive even in comparison with Eastern Europe.

Another set of changes sought to shift urban areas from a consumption to a production emphasis. This effort had several dimensions. First, and foremost, there was a reallocation of economic priorities which involved major investment in industry (especially heavy industry), construction, and human capital, and a deemphasis on consumer goods and personal services. Some trades were phased out or banned entirely (e.g., prostitutes, rickshaw drivers), certain people in trades deemed too crowded (jewelry making, tailoring) were transferred into other lines of work, and many small consumer-oriented shops were consolidated into larger collectively financed or state-run stores. Another dimension involved the effort to reduce the proportion of the urban population that was dependent upon others, an effort pursued through a variety of means - mobilizing housewives for work outside the home, sending "excess" urbanites down to the countryside, and fostering birth control, for example. In many other ways a spartan and productive urban atmosphere was promoted. Wedding feasts were discouraged, traditional holiday celebrations were shortened or ignored, fairly uniform "proletarian" styles of dress were encouraged, stints of athletic competition and manual labor became regular parts of life for all, and new plays and novels popularized the modest life styles of the new age. These emphases differ only in degree from those that characterized the Soviet Union in Stalin's time, although since the 1950s a shift back partially in the direction of catering to consumer needs has been visible in much of Eastern Europe. 
Another set of changes was designed to provide greater security for urbanites. This involved first an effort to eliminate inflation and then to enhance security through the employment systems and rationing network already described. Jobs in the state sector also brought with them an impressive range of fringe benefits. ${ }^{3}$ One was eligible for full medical insurance for oneself and partial medical insurance for dependents, sick leave pay, disability insurance, paid maternity leave, retirement pensions, subsidized housing, and in many cases even subsidies for things like busfare and haircuts. Also important were the expansions of schooling and of medical care facilities that took place in cities, which were designed to make urbanites feel that resources that had formerly been used mainly by the wealthy were now within reach of all. These measures do not differ in major ways from the "welfare state" emphasis common in socialist Eastern Europe.

A final set of institutional changes involved the effort to promote equality among urbanites - both equality of opportunity and equality of results. These efforts received particular emphasis during the Cultural Revolution decade. On the one hand various kinds of bonuses, incentive payments, and royalties were eliminated, placing employed persons on fixed wage scales. Although their wage ranks remained significantly differentiated (with, for example, a ratio of 3 to 1 between the pay of the highest grade factory worker and the lowest grade - see Korzec and Whyte 1981), some people in the highest wage ranges were demoted while wage increases were provided in 1971-2 for those at the bottom, compressing the differentials somewhat. Symbols of status were also attacked, and military ranks, graded titles (professor, assistant professor) and so forth were eliminated. In most cases the former holders of such titles continued to carry out their duties, and so company commanders could still give orders to new army recruits. But some experiments were made with role reversals, such as having doctors empty bedpans while nurses experimented with surgery and orderlies gave injections. Many highly placed bureaucrats and intellectuals had to move out of spacious housing into cramped quarters or even into the countryside, while some of their former subordinates moved up into the vacated premises (Whyte 1981).

Even more interesting were efforts to block the transmission of high status from one generation to the next. It was recognized that children from well educated families (families that often had "impure" class backgrounds as former capitalists and merchants) had tended to do better and go further in school, and thus get assigned to better jobs, than youths from less well educated families, even long after the revolution. This is hardly a surprising phenomenon even for a socialist society (see Connor 1979; Yanowitch and Fisher 1973). Before 1966 a system of competitive examinations was utilized to allocate students to the best schools and into the universities, as in many other societies. The Cultural Revolution eliminated this. After 1968, when schools reopened, students proceeded upward through designated neighborhood primary and secondary schools without examinations, but it was no longer possible to go directly from secondary school to college. Instead, secondary 
school graduates had to go out into society, either by being assigned an urban job, joining the army, or going to the countryside. The latter was the fate of most urban youths.

When universities began to reopen after 1970 they chose their new students in a novel way - by recommendation from work units, communes, or military units. Young people could express an interest in going to college, but it was up to the local authorities to decide whom they would nominate, and they were directed to consider criteria such as a youth's class background, work record, political activism, and relationships with fellow workers in order to gauge worthiness for advanced education. Entrance examinations were not used, and even the youth's former academic record in secondary school was not supposed to be a factor. Even those fortunate enough to be assigned to the army or an urban job rather than rural rustication were to be selected by school administrators in terms of their class background and political record, rather than their academic credentials. By short-circuiting the connection between academic performance in school and one's later fate, the Cultural Revolution radicals felt that they could provide the basis for greater equality of opportunity.

Although there have been important egalitarian impulses in East European socialism - for example, in the Soviet Union in the 1920s and briefly again under Khrushchev in the 1950s (Moore 1950s; Feldmesser 1962) - in no instance was a set of reforms designed to dismantle meritocracy and material rewards and strive for equality of opportunity and results pursued as systematically as in China during the Cultural Revolution. Taken as a whole, however, the Chinese approach to urbanism is best regarded as a variant of an established socialist pattern, but one that goes much further in fostering bureaucratic allocation, tight-knit organizational control, and egalitarianism.

I have noted that the Chinese elites who pushed these reforms anticipated that by creating these altered institutional forms they would be creating the conditions to make possible the elimination of previous urban "evils" and the promotion of a highly committed, solidary, and involved style of urban social life. How realistic were these expectations, though? Were the Maoists perhaps engaged in a utopian struggle against certain imperatives of urbanism, as Wirth might have argued? Do the claims for the successes of the "Maoist model" of urbanism have any real basis? It is to these questions that I now turn.

\section{The Social Consequences of Urban Transformation}

In many ways these institutional changes must be judged quite successful. Let us consider some of the details. Clearly "overurbanization" has been avoided. Indeed, although the economy has developed at a relatively rapid, albeit uneven, pace since 1949, the proportion of the population living in urban areas has been kept more or less constant. Chinese sources claim that in 1953 about $13 \%$ of the population lived in cities above 100,000 and that in 
Table 1

\begin{tabular}{lccc}
\multicolumn{4}{c}{ The Utban Population in Low Income Countries } \\
\cline { 2 - 4 } & $\begin{array}{c}\text { GNP/capita in 1978 } \\
\text { (in US dollars) }\end{array}$ & $\begin{array}{c}\text { \% of population } \\
\text { urban }\end{array}$ & $\begin{array}{c}\text { \% of ur- } \\
\text { bantites in } \\
\text { largest city }\end{array}$ \\
\hline $\begin{array}{l}\text { China } \\
\text { 24 low income } \\
\text { countries* } \\
\text { (Range) }\end{array}$ & 230 & 16 & 5 \\
\hline
\end{tabular}

* median, weighted by country population

Sources: China - Whyte and Parish 1983, Chap. 2.

Others - World Bank, World Development Report, New York:

Oxford University Press, 1980.

1978 the comparable figure was still about $13 \%$ (Orleans 1982). The cities that have grown most rapidly have not been the largest coastal cities, as is commonly the case in the Third World, but medium-sized (100,000-l million) cities in the interior. Furthermore, China's largest city, Shanghai, actually experienced a decline for a period, from more than 7 million in 1957 to only about 6 million in 1973 (Howe 1981). The people we interviewed generally confirmed the view that it was exceedingly difficult for peasants to establish themselves in China's large cities without permission, and that there were very few such individuals in the neighborhoods where they lived. Scholars such as Gur Ofer and Ivan Szelenyi have argued that in general East European societies are "underurbanized." (Ofer 1976; Szelenyi 1981; Konrad and Szelenyi 1974) In other words, they tend to have smaller proportions of their populations living in urban places than do capitalist societies at comparable levels of economic development. The figures in Table 1 make it fairly clear that China also fits this pattern of underurbanization.

The effort to make cities more productive has also been fairly successful. For one thing, the percentage of the urban population employed increased from about $30 \%$ in the early $1950 \mathrm{~s}$ to $55 \%$ in the late $1970 \mathrm{~s}$, indicating a dramatic drop in the number of non-wage earners who had to be supported by their families or the state. (Zhongguo Jingji Nianjian 1981, p. VI-25) One trend that contributed to this shift was the exodus of housewives from their homes and into the workplace after the mid-1950s. We estimate from our interview data that about $90 \%$ of all urban women in the 20-50 age range were working in full-time jobs in the mid-1970s. The figures in Table 2 reveal that this is an impressively high rate of female employment, even in comparison with the more developed societies of Eastern Europe.

Equally as clear are shifts in the distribution of nonagricultural employment in China. By 1957 socialism had been established and the Stalinist pat- 
Table 2

Percentage of Labor Force Female

\begin{tabular}{lcc}
\hline \multicolumn{1}{c}{ Countries } & Median & (Range) \\
\hline China & $48 \%$ & $\ldots$ \\
$\begin{array}{l}\text { 8 European } \\
\text { socialist states }\end{array}$ & $44 \%$ & $(29-50 \%)$ \\
$\begin{array}{l}\text { 16 Euro/American } \\
\text { capitalist states }\end{array}$ & $33 \%$ & $(22-44 \%)$ \\
$\begin{array}{l}10 \text { Asian } \\
\text { developing states }\end{array}$ & $28 \%$ & $(10-44 \%)$ \\
\hline
\end{tabular}

Sources: China: Weighted sample of employed neighbors.

Others: Computed from non-agricultural labor force data in 1977 Yearbook of Labor Statistics (Geneva: International Labor Organization, 1977).

tern of economic priorities had already produced a clear shift in favor of fields like heavy industry and construction. Still, in the two decades after 1957, a further shift in the same direction occurred (see Table 3), which even more deemphasized services other than education and health care. In Table 4 the consequences of these shifts can be seen in comparative perspective. There we see that, in spite of China's much lower level of economic development, the profile of nonagricultural employment looks quite similar to that in Eastern Europe, and quite different from that found in developed capitalist economies or in the Third World. These statistics attest to a contrast that is clear even to casual observers who visit cities such as Hong Kong, Singapore, or Taipei, and then cities in the PRC. In place of the untidy profusion of tourist shops, streetcorner trinket sellers, and attractions to the palate ranging from roving snack sellers to magnificently decorated restaurants, visitors to Chinese cities in the mid-1970s could see a narrow range of drab but functional stores, canteens, and workshops, all overshadowed by major factory complexes nearby.

Considerable success was also achieved in promoting stability and solidarity. The combination of factors such as lifetime employment, bureaucratic controls on changing jobs and housing, and obligatory participation in grassroots meetings and activities promoted social relations quite different from the Wirthian image of impersonality and anonymity. We calculated that the average length of residence in one place of family heads in the weighted sample from our interviews was 18 years, an impressive testimonial to the stability of social networks since 1949. ${ }^{4}$ The fact that large numbers of families are forced to share kitchens and toilets with their neighbors also increases familiarity, although not necessarily solidarity. We found that our interviewees showed a range of knowledge about their nearest neighbors that would be hard to imagine in America or most other societies, and this familiarity about such things as the monthly wages and division of domestic chores in neighboring families 
Table 3

The Non-Agricultural Labor Force by Industry and Year

\begin{tabular}{|c|c|c|c|}
\hline Industry & 1957 & 1978 & $\begin{array}{c}\% \\
\text { Change }\end{array}$ \\
\hline $\begin{array}{l}\text { Manufacturing and Mining } \\
\text { Construction }\end{array}$ & $\begin{array}{l}34.5 \% \\
6.6\end{array}$ & $\begin{array}{r}47.9 \\
7.9\end{array}$ & $\begin{array}{l}+39 \% \\
+20 \%\end{array}$ \\
\hline $\begin{array}{l}\text { Health } \\
\text { Education, Cultural } \\
\quad \text { and Scientific Affairs }\end{array}$ & 1.7 & 12.0 & $\begin{array}{l}+142 \% \\
+48 \%\end{array}$ \\
\hline $\begin{array}{l}\text { Urban Public Utilities } \\
\text { Government Administration } \\
\text { and Mass Organization }\end{array}$ & 0.4 & 0.3 & $\begin{array}{l}-15 \% \\
-30 \%\end{array}$ \\
\hline $\begin{array}{l}\text { Transport, Post and } \\
\text { Telecommunications } \\
\text { Trade, Restaurants, and }\end{array}$ & 12.9 & 8.4 & $-35 \%$ \\
\hline $\begin{array}{l}\text { Insurance } \\
\text { Other Services }\end{array}$ & $\begin{array}{l}1.9 \\
1.5\end{array}$ & $\begin{array}{l}0.7 \\
0.4\end{array}$ & $\begin{array}{l}-65 \% \\
-76 \%\end{array}$ \\
\hline & $100.0 \%$ & $100.0 \%$ & \\
\hline
\end{tabular}

Sources: Statistical Bureau, Statistical Work in New China (Beijing, November 1979), adapted by John Philip Emerson, "Growth of Nonagricultural Employment in the People's Republic of China," paper delivered at the conference on China's population, Hawaii, May 1980.

was what made our research possible. And although the people we interviewed had decided for a variety of reasons to leave China and come to Hong Kong, almost without exception they said that ties among neighbors and workmates were closer and characterized by more "human feelings" in the cities where they had lived than in Hong Kong, where they saw social relations fitting the Wirthian stereotypes quite closely.

This interpersonal familiarity is partly, as noted, a consequence of the penetrating organizational system that was built up in work units and neighborhoods, and the success of this system in exerting social control is also impressive. Activities that were seen as rampant social evils before $1949-$ e.g., prostitution, crime, secret society extortion, gambling - were, if not totally eliminated, at least sharply reduced in scale. So, for example, observers accustomed to the round-the-clock din of mah-jong tiles in Hong Kong or the zeal with which Chinese flock to the casinos in Macao find it remarkable that what seemed like a national craze for gambling has been reduced to occasional furtive card games between close friends behind closed doors in the PRC. Other examples of the success of the authorities in producing major changes in behavior patterns can also be pointed out - the ability to mobilize 17 million urban youths to settle down in the countryside, or to induce parents in a highly pro-natalist culture to limit themselves to two children or even one. On a more 
Table 4

The Non-Agricultural Labor Force by Industry and Type of Economy<a>

\begin{tabular}{lcccc}
\hline & \multicolumn{2}{c}{ Market Economies } & \multicolumn{2}{c}{ Socialist Economies } \\
\cline { 2 - 5 } & U.S. & $\begin{array}{c}\text { Developing } \\
\text { Societies }<\mathrm{b}>\end{array}$ & China & $\begin{array}{c}\text { Eastern } \\
\text { Europe <c }>\end{array}$ \\
\hline Manufacturing and Mining & $28 \%$ & $27 \%$ & $48 \%$ & $46 \%$ \\
Construction & 5 & 8 & 8 & 10 \\
Transport and Public Utilities & $\mathbf{8}$ & 9 & 9 & 11 \\
Finance & 5 & 2 & 1 & 1 \\
Trade, Restaurants, and & 21 & 21 & 12 & 10 \\
$\quad$ Hotels & 33 & 33 & 22 & 22 \\
Government and Other Services & $100.0 \%$ & $100.0 \%$ & $100.0 \%$ & $100.0 \%$ \\
Total & & & & \\
\hline
\end{tabular}

$<a>$ Except for China, all about 1970.

<b > Twelve societies with 1970 per capita GNP of less than $\$ 1,200$, ranging from the poorest, India, to the richest, Argentina.

$<c\rangle$ Four states - East Germany, Hungary, Poland, and Romania.

Sources: China - table 3. U.S. - U.S. Bureau of the Census, Statistical Abstract of the U.S., 1976 (Washington: U.S. Government Printing Office, 1976), table 597. Others United Nations, Demographic Yearbook, 1972 New York, 1973), table 10, and Demographic Yearbook, 1973 (New York, 1974), table 40.

mundane level, in any other society it is hard to imagine the 1972 scene of Peking residents rousted out in the middle of the night to sweep the new-fallen snow off the streets President Nixon would traverse the next day.

The pursuit of security also made clear progress. Inflation was brought under control by about 1951, and over the years not only was an increasing proportion of the urban population employed (producing higher family incomes even with no change in wage levels), but more and more worked in the state sector of the economy where they were entitled to the wide range of fringe benefits previously noted. Widespread begging and squatter settlements disappeared, and the extensive rationing system eliminated hoarding in the most basic commodities. Schools and health care facilities grew rapidly and were increasingly seen as within reach of all urbanites, rather than monopolized by the wealthy. In certain respects, though, living standards increased quite slowly. For example, while the worst slum areas were cleared, the Stalinist emphasis on productive investments resulted in little being spent on new housing after the mid-1950s, so that much urban housing decayed into a seedy condition and actual living space per person declined. Still, most of the urban population 
Table 5

Income Inequality by Type of Household and Society

\begin{tabular}{lccc}
\hline Urban Households & $\begin{array}{c}\text { Gini } \\
\text { Coefficient }\end{array}$ & $\begin{array}{c}\% \text { Income Earned } \\
\text { by Richest 10\% } \\
\text { of Households }\end{array}$ & $\begin{array}{c}\% \text { Income Earned } \\
\text { by Poorest 40\% } \\
\text { of Households }\end{array}$ \\
\hline $\begin{array}{l}\text { China } \\
\begin{array}{l}\text { Developing Market Societies< }<> \\
\text { Average (mean) } \\
\text { Range (Taiwan-Ecuador) }\end{array}\end{array}$ & .25 & $21 \%$ & $25 \%$ \\
\hline
\end{tabular}

Sources: China - Sample of neighbor households.

Other societies - Shail Jain, Size Distribution of Income (Washington, D.C.: International Bank for Reconstruction and Development, 1975).

Notes: (1) The data for the other countries is for the urban population while the Chinese figures are for the non-agricultural population, but this should make little difference in the results, judging from non-agricultural data in Jain.

(2) All figures describe the distribution of households by total household income in each country or set of countries.

$<a>$ Twenty-four market societies with a 1970 per capita gross national product of less than U.S. $\$ 1200$ and population greater than one million.

could at least take comfort from the fact that most of the economic insecurities of urban life had been eliminated.

The efforts made to foster greater equality in urban areas are especially interesting. It is often argued that incomes tend to be modestly more equally distributed in socialist than in capitalist societies, but that many forms of inequality remain, and that leading bureaucrats and intellectuals have access to a wide range of special privileges, and their children manage to do quite well also (see, for example, Connor 1979; Szelenyi 1978). The Chinese elite, or at least the Maoist elements during the Cultural Revolution, wanted to do better than this. We get some idea of the results of their efforts by examining the figures in Table 5. From Table 5 one can see that our estimate of income distribution for urban China in the mid-1970s shows somewhat more equality than in any of the comparison countries. It is interesting to note, however, that the "best" of these other cases is Taiwan, where a capitalist economy operating in a Chinese context does not show significantly more inequality of incomes than in urban areas of the PRC.

But if it is true that in a socialist society bureaucratic allocation makes rank more important than income in determining access to scarce goods and services, then perhaps income distribution comparisons are not so relevant. We collected some data on the consumption of various consumer durables, and in Figure 1 we can examine whether consumption levels were closely related to occupational rank in the 1970s. Although we have no basis here for comparisons with other countries, in general the plots in Figure 1 do not appear to be particularly steep. Only in regard to the scarcest items, television sets and 


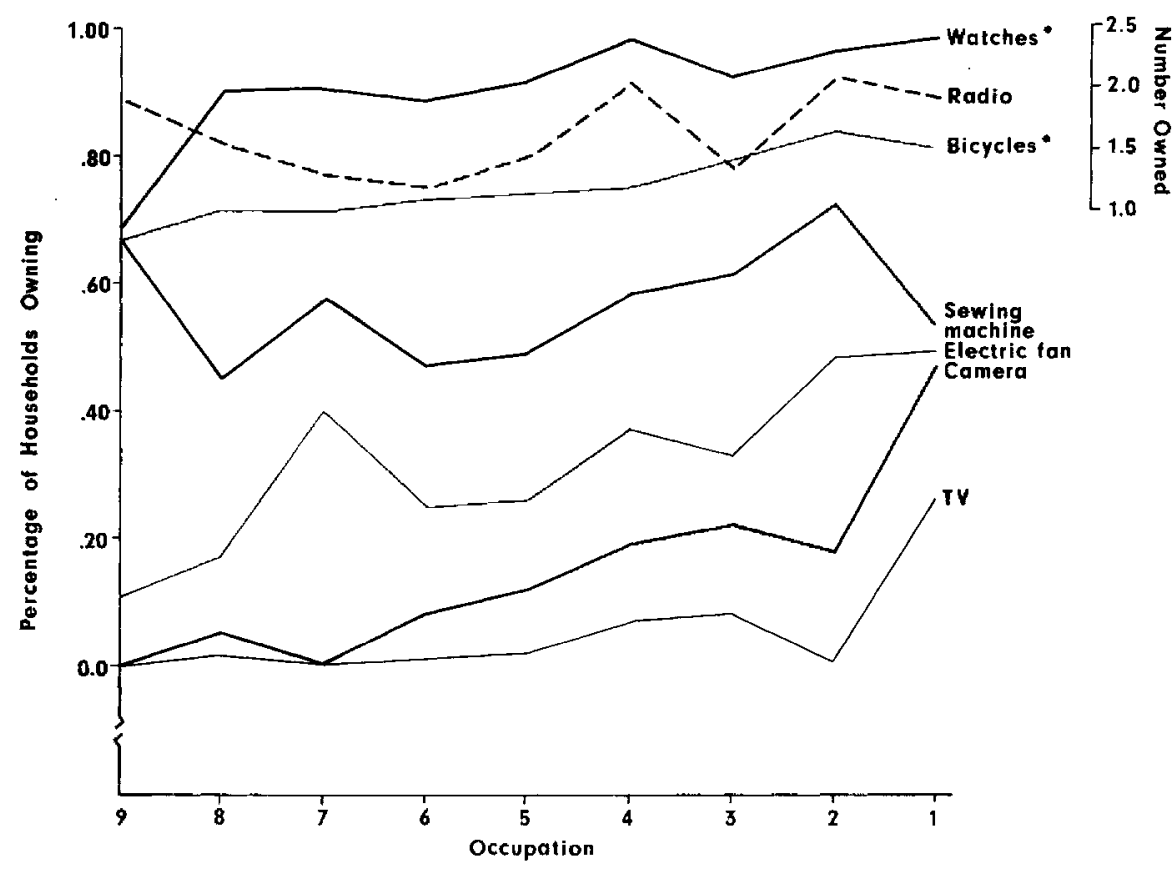

Fig. 1. Occupational Rank and Consumption.

* Watches and Bicycles are indexed on the right side, others on the left

1-High professionals 2-Administrative cadres 3-Low professionals
4-Managerial cadres

5-Clerical \& sales

6-Skilled manual

\author{
7-Service workers \\ 8-Ordinary \& semi-skilled \\ 9.Unskilled \& marginal
}

cameras, do high professionals show a clear advantage. Otherwise consumption levels do not seem to be tied closely to occupational rank. These figures suggest relative equality of consumption as well as incomes in urban China. ${ }^{5}$

Even more intriguing are the data we collected on educational and occupational mobility, which are presented in Table 6 . There we can see quite different patterns for the cohorts who reached age 20 before the Cultural Revolution and afterward. In the pre-1966 cohort the familiar pattern of youths with advantaged fathers doing better than other youths is visible. (The figures show, incidentally, that offspring of parents with "impure" class backgrounds continued to do better than the children of workers, soldiers, and poor peasants during this period.) In this earlier cohort about a third of the variance in schooling and jobs is explained by the other variables listed. In the post-1967 cohort, in contrast, the links between the father's characteristics and the child's success largely disappear, as does the advantage of sons over daughters, for the most part. As a result, the fates of young people in this cohort are much less 


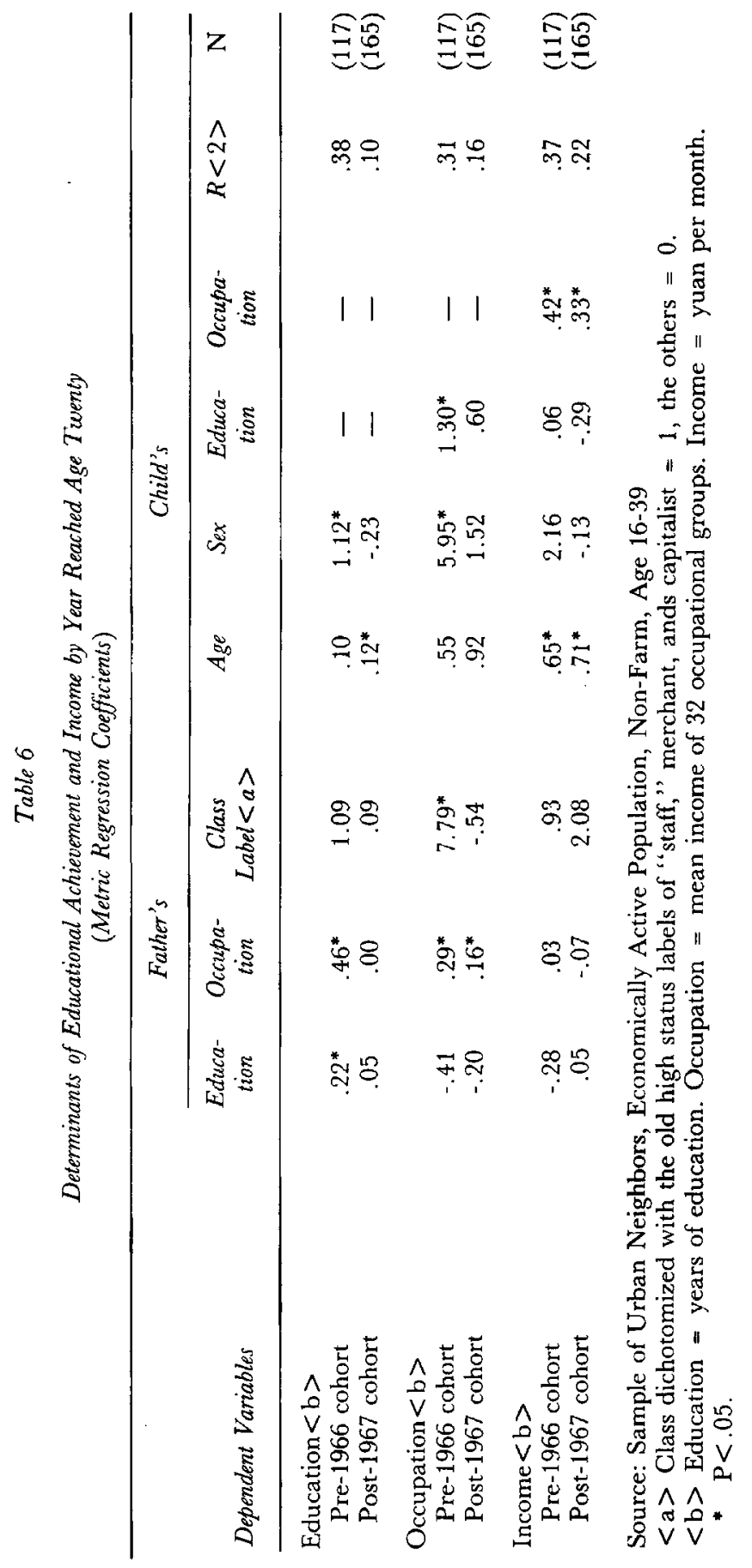


"predictable," as the lower values of R-squared show. These figures make it appear, then, that the changes in the systems of schooling and job-placement that resulted from the Cultural Revolution largely eliminated the advantages of young people from high status families. (Again, however, our figures do not speak to the fate of children of those of the most exalted ranks - see footnote 5.) Coleman (1974) once argued that "family effects" on school performance were so pervasive that the only way to really insure equality of opportunity would be to take infants away their families and rear them in some sort of uniform manner. Our figures suggest that the Cultural Revolution alternative of eliminating the role of the schools in social mobility largely overcame these "family effects," at least for a period.

In many respects, then, urban areas in China had been fundamentally transformed after 1949. By the mid-1970s they differed in appearance, composition, and organizational forms from the urban areas captured by the CCP only a generation earlier. In many ways the changes were successful in promoting forms of urbanism that conformed to the values of the communist elite, and which differed in important regards from the prevailing images of urbanism in Western sociology. In some respects the result was that Chinese cities became quite similar to cities in socialist Eastern Europe, and quite unlike cities elsewhere in the Third World, making it clear that any simple equating of forms of urbanism with levels of development is untenable. But in a number of significant respects - particularly in regard to controlling city growth, fostering population stability, developing a penetrating organizational system, and promoting equality of opportunity - the "Maoist model" of urbanism appears distinctive even in regard to Eastern Europe. Given these apparent successes in developing distinctive urban forms, it is interesting to note that China's post-Mao leadership has begun to attack and modify a number of the features of this Maoist model. In the following pages I wish to analyze the reasons for these attacks and the nature of the modifications now taking place.

\section{The Retreat from the Maoist model}

China's post-Mao leadership has operated in a state of perceived crisis and has used this atmosphere to repudiate many of the policies of the Cultural Revolution and even to question some of the institutional changes made in earlier years. In part this is simply an old story of a victorious faction trying to undo the work of their enemies, but it is also clear that the urban innovations introduced in the preceding period had unanticipated and harmful consequences. What, specifically, went wrong?

First, and perhaps foremost, the original conception of Chinese socialist urbanism was based on the idea that each urban youth could look forward to getting educated and being assigned to a secure urban job, but that expectation could no longer be met in the 1960s and 1970s. The baby boom of the 1950s, the emphasis on the capital-intensive sector of the economy, and some significant downturns in the economy (notably after the failure of the Great Leap 
Forward campaign of 1958-60) all combined to produce a situation in which there were many more school-leavers each year than there were new urban jobs available. (Factors such as the relative youth of the urban labor force and Cultural Revolution restrictions on private enterprise aggravated the problem.) By the carly 1960s, urban unemployment, apparently brought under control in the late $1950 \mathrm{~s}$, began to mushroom again.

The solution adopted by the authorities was to "deport" unemployed youths to the countryside. But the 17 million urban youths who were rusticated did not, unfortunately, end up contentedly working in the countryside. Large numbers of them began to sneak back to the cities illegally. Without urban registrations they were unable to work legally, but unlike a true rural migrant they had families and friends who could help them survive in the city. With no stake in the urban system and a certain invisibility owing to not being recognized members of work units or neighborhoods, these youths in many cases turned to black marketeering, picking pockets, robbery, and similar kinds of deviance. Eventually some coalesced into juvenile gangs that engaged in ritualized battles for "turf" with rival gangs, using zip-guns and other makeshift weapons. So for urbanites accustomed to thinking that socialism meant improved law and order, there was an alarming rise in crime.

Unemployment and juvenile delinquency were parts of the more general problem of a lack of predictable opportunities for young people. The Maoist reforms may have fostered equality of opportunity, but they also made urban youths see their prospects in life as both dim and unpredictable. They could gain access to schooling, to be sure, but no matter how hard they studied or applied themselves in other ways they knew that upon graduation they would probably be assigned to the countryside. On the other hand, no matter how poor their school performance or even the regularity of their attendance, they knew that they would be promoted from year to year until graduation. So much of the connection between present performance in school and future opportunities was removed, and student motivations and academic quality plummeted.

Not only young people but the entire urban work force was affected to one degree or another by the dismantling of the incentive structure and career ladders that had previously existed. Employed urbanites found their wages frozen and bonus payments gone, and they also knew that if they worked poorly or took sick leave they would continue to receive their fixed wages as usual. So absenteeism, pilfering, and shoddy work increased during the Cultural Revolution. As a result of the poor productivity of the work force, the authorities found they had to invest at an increasingly high rate just to maintain an acceptable pace of growth. So instead of finding that the Maoist reforms released untapped energies of "the masses," critics charged that they made economic development unnecessarily expensive.

Consumer frustrations also abounded in this period. The presumption behind the bureaucratic allocation system was that urbanites would be able to satisfy their basic needs at modest costs and could perhaps gradually enjoy an 
improved standard of living. But in fact urbanites with their wages frozen found it difficult to cope with family needs even in the absence of inflation, especially if they had unemployed or rusticated children to support. As noted earlier, the prevailing investment priorities led to a decline (by 20\%) in the housing space per capita between the early 1950s and the late 1970s (see Zhou 1979), and the inability of urbanites to arrange for better accommodations became a special sore point. Goods were also not always available, even with the rationing system, making it necessary to spend long hours in lines to buy needed food and other items. Again the prevailing production emphasis meant that families had to cope with laundry, cooking, and other onerous chores with little help from appliances or public service facilities, and as a result the one day off per week of urban workers often was swallowed up by work on such chores. Indeed, one recent Chinese time-budget study argues that Chinese urbanites have to spend about $50 \%$ more time per day on chores than do people even in other socialist societies (Wang and Li 1982).

The bureaucratic obstacles and delays involved in the pursuit of scarce goods, new housing, medical care, and other resources produced constant frustrations. But they also brought out the resoucefulness of the Chinese, who could use the "back door" of personal connections to gain access to goods and services otherwise not available. Everyone was forced to play this game, and people with particular access to such resources - e.g., doctors, shop clerks, and housing office cadres - became very popular. But as a consequence of the ubiquity of "going by the back door," popular faith in the efficiency and equity of the official distribution system was undermined. Since those in the best position to use the distribution system to their own advantage were the high ranking bureaucrats and party cadres, urbanites began to perceive that their frustrations were the product of the ample "back doors" of those in high places. Since the resources involved ranged all the way from purchasing fresh fish to gaining university admission for a son or daughter, it is easy to understand the depths of the resentment engendered. The post-Mao leadership recognized that, as in Poland, consumer frustrations and the hypocritical contrast between egalitarian ideology and special privileges of the elite can be politically explosive, and they felt that some changes had to be made.

Further problems were associated with the heavy stress on bureaucratic allocation and the related high degree of corporateness promoted in urban organizational life. While it had been hoped that such features would produce solidarity and security, and as a result lead to high productivity and activist participation in political affairs, the reality was often quite different. In the absence of technical standards for evaluating behavior and of material incentives, the authorities increasingly used political slogans, praise, and threats to mobilize subordinates, and all realms of thought and behavior came to be seen in terms of ideological virtue or deviation. To this was added the growing factional struggles that accompanied the period leading up to Mao's death in 1976. As a result urbanites found themselves in increasing danger of being politically victimized, often for trivial causes or out of personal spite or factional intrigue. 
In this sort of atmosphere the understandable response of many was to try to do whatever was necessary to stay out of trouble, but not to stick one's neck out and attract attention. So a style of ritualized compliance, rather than activist involvement, was fostered. Currying favor with superiors became common, but it was a risky game, since one's patron today might be purged tomorrow. These interpersonal tensions were made more complex by the legacy of the system of permanent employment. Being unable to move to different jobs, some people found themselves locked into daily interaction with others who had denounced them (or vice versa) ten or twenty years earlier. Long suppressed personal animosities came to the surface and were expressed under the campaigns and slogans of the Cultural Revolution decade. In sum, the economic security that had been gained was to a considerable degree offset by the political insecurities that developed during these years.

By the mid-1970s, then, a number of behavioral tendencies that were seen as undesirable - passive compliance, sycophancy, forming of personalized factions - were clearly being fostered. Equally important were the consequences of the institutional changes for those in positions of authority. The Cultural Revolution has been seen by many, in the West as well as in China, as profoundly anti-bureaucratic in thrust, designed to foster humility on the part of superiors and active involvement and criticism of abuses of power by subordinates (see, for example, Whyte 1973). Again the reality was often far different. The lack of autonomy and alternatives forced subordinates into neartotal subservience toward those who ran their organizations, and those in power found they could use their sycophantic subordinates to a number of ends, including struggle with declared factional opponents and the quest for personal advantage. As a consequence, the prevailing organizational system fostered bureaucratic arrogance and abuses of power, rather than the desired humble public servant orientation (see also Walder 1982). But one way organizational leaders did not use their authority was to pursue organizational goals innovatively. Since they were, in turn, locked into a politicized and factionalized environment in relation to their own bureaucratic superiors, they tended to employ the same sorts of risk-minimization strategies that were used by their subordinates. Given the highly bureaucratic nature of the administrative system, with many levels of "chops" needed to approve any new activity, the result was to increase further preexisting tendencies toward bureaucratic immobilism.

Thus, while the urban reforms introduced by the CCP transformed the nature of urban society and successfully combatted many perceived "evils of urbanism," at the same time they generated a range of new and serious problems. Instead of the promised solidary and orderly urban environment, urbanites in the 1970s increasingly perceived that they were living in an arbitrary bureaucratic system that only irregularly met their needs, an environment in which one had to play all the angles and cultivate personal ties to maintain security and gain access to resources. In this sort of setting, when individuals felt frustated or abused, they were not likely to blame their own failings, the 
vagaries of the market, or simply fate. Instead they were likely to blame the Party and state which claimed to be benevolently providing for them. Hence, China's post-Mao leaders felt that they were faced with an authority crisis that was due in substantial part to the policies and institutions of the Cultural Revolution. This provided the justification for the attacks on the Maoist model of urbanism and the reforms that have been introduced since 1977. A full discussion of these reforms is not possible here, but a simple enumeration of some of the most important changes should convey their thrust.

The post-Mao leaders have taken a wide variety of steps to renounce solidary egalitaranism and to restore competitive meritocracy. Examinations, grades, and academic competition for placement in high quality "keypoint" schools and universities have become the rule. The program of sending urban youths to the countryside is being phased out, and efforts are underway to emphasize light industry, collective enterprises, and even private enterprise in an effort to combat the unemployment problem. For the first time in more than a generation foreign firms are being invited to set up enterprises in China as part of a strategy to acquire new technology and expand the number of available jobs. Once employed, urbanites now find a complex structure of bonuses, piece rates, and other material incentive devices back in vogue, and are told that diligent efforts now will lead to promotions in the future. Large numbers of specialists who had been working at jobs for which they were not trained are being transferred to work more appropriate to their talents, and intellectuals are being offered a wide range of benefits in regard to housing and working conditions in order to stimulate their efforts. These policies are all designed to rebuild a predictable opportunity structure that ties current behavior to future rewards and emphasizes expertise over political virtue. If in the process somewhat greater differentials in income and consumption are fostered, and even inheritance of advantages, the post-Mao leaders are on record as saying that this is acceptable, or even desirable, as part of the modernization effort (see Whyte 1981).

At the same time the government has taken steps to remedy problems in the distribution system. By reforming rural production organizations in a comparable incentive-oriented way, allowing peasant "free markets" in the cities, encouraging free enterprise activity, and investing more in consumer goods industries and in urban housing, the authorities aim to increase the availability of supplies and reduce consumer frustations. At the same time they have instituted new disciplinary procedures and have publicized cases of graft and corruption, including the executions increasingly used to combat "economic crimes," all as part of the effort to restore faith in the distribution system.

A number of efforts are also underway to reduce the fear of political victimization. For the first time since 1949 a comprehensive legal system is being introduced, and citizens are being assured that there will be equality before the law. Large numbers of authority figures who are said to have abused their positions have been purged, but the population is being told that no large-scale political struggle campaigns will occur in the future. Many individuals who ran 
afoul of the authorities in the previous period have now been "rehabilitated," and the populace is being told that class origin labels will no longer be used to discriminate against those from "bad class" families. Various mechanisms for selecting and promoting officials based upon qualifications and contributions, rather than on political background or simply seniority are being experimented with. And a range of experiments in decentralizing decision-making, relying more heavily on market forces, using profitability rather than physical targets to judge success, and allowing some retention of profits locally are being tried in an effort to break the rigid bureaucratic constraints within which grass-roots enterprises have had to operate.

\section{Conclusions}

To many observers the post-Mao changes seem drastic indeed, amounting to a near total repudiation of the Maoist models of social organization that emerged during the Cultural Revolution. When examined in detail, however, the changes to date are neither unprecedented nor very far-reaching. Students of East European socialism understandably have a sense of deja-vu when hearing of these post-Mao reforms. For although the Chinese had developed some rather distinctive institutions and policies, still the effort to reform the highly bureaucratic "command economy" to provide the complexity and flexibility needed in a modernizing economy is a familiar story. More specifically, the effort to reduce problems of bureaucratism, poor productivity, lines and shortages, and caprice of authorities by experimenting with administrative decentralization, legal codes, market mechanisms, increased tolerance for private enterprise, and growing autonomy for managers and intellectuals all have clear parallels in the reform efforts begun in Eastern Europe and the Soviet Union in the $1950 \mathrm{~s}$.

If the Eastern European precedent is our standard of comparison, then it should also be clear that the post-Mao reforms to date involve much less extensive changes than in countries such as Hungary and Yugoslavia, and something more on the order of the partial and "two steps forward, one step back" reforms implemented elsewhere in Eastern Europe. In a sense the Chinese reforms involve a repudiation of the extreme egalitarianism of the lateMao era, but in other respects represent more a return to a conventional command economy rather than a dismantling of direct allocation in favor of market prices and market-based distribution. Many features of the urban organizational system discussed earlier remain much the same as before. For example, urban migration restrictions remain very much in force, prices continue to be centrally fixed for most products, and urbanites still depend heavily upon resources controlled by the authorities in the tightly-organized work units and neighborhoods in which they work and live. There have been "trial balloon" proposals that individuals be allowed to change jobs at their own discretion or build their own private homes, but so far such proposals seem very controversial and of questionable practicality in China's urban system. Hence, I would 
argue that the extensive series of post-Mao reforms involves for the most part little more than tinkering with the basic urban organizational forms built up in the 1950 s.

The foregoing observations lead me to argue that what we see here is not some sort of triumph of rationality over Maoist utopianism, but one more instance of a general set of dilemmas or tradeoffs involved in the process of development, whether under socialist or capitalist auspices. This set of tradeoffs has been discussed by others in terms of equality versus efficiency, politics versus markets, or similar phrases (see Okun 1975; Lindblom 1977; see also Stinchcombe 1959 and Walder 1981). An emphasis on features such as markets, efficiency, and individual choice may result in flexible administration, high productivity, organizational innovation, and responsiveness to consumer demands, although none of these is automatically guaranteed. But by the same token such emphases may also entail inflation, unemployment, conspicuous consumption, transmission of privilege, and other perceived "evils." An emphasis on direct allocation, bureaucratic control, and equality, on the other hand, has a different set of benefits and costs. Relative equality, stable prices, and effective regulation of undesirable behavior may be fostered, but at the same time bureaucratic rigidity, inefficiency, consumer frustration, and arbitrary victimization tend to be unwanted byproducts.

Seen in this context, the Chinese Communists are swinging on a familiar pendulum. They developed a set of institutions and policies that stressed bureaucratic allocation and equality to an unusual extent, and now the costs of that choice have led them to backtrack and search for a more "mixed" set of organizational orientations that will reduce those costs. Even this modest swing of the pendulum backward has generated controversy. Inflation surged upward in 1980 after a generation under control, complaints were voiced against the harsh competition and special privileges entailed by the new meritocratic emphasis, and critics charged that foreign influences and ideas were subverting society and leading to alienation, sexual experimentation, and crime. Perhaps more important, it is probable that the millions of bureaucrats who rose into positions of power largely on the basis of political credentials during the previous generation will not be eager to see individuals with academic credentials or technical skills move up past or displace them. In sum, many of the kinds of resistance and obstacles that have stymied or even rolled back decentralizing reforms in the Soviet Union, Czechoslovakia, and Poland are clearly visible in China, and it remains to be seen whether these can be overcome or not.

What does my analysis of the Chinese case tell us about theories of urbanism? Neither the Wirthian view of urban universals nor the neo-Marxist analysis seems adequate to interpret the Chinese case. The characteristics focussed on by Wirth and his followers do not appear to be inevitable concomitants of urbanism, and they do seem to have their roots at least in part in the market exchange systems that exist in developed capitalist societies. When the Chinese Communists set out to transform their cities they did succeed in 
producing social relationships that were at least in significant ways different from the prevailing image of impersonal, cash-oriented urban relationships. But contrary to the neo-Marxian view, development of socialist cities did not necessarily lead to an elimination of all of the urban ills of capitalism unemployment, for example, proved difficult to eradicate. At the same time the new urban forms that were built engendered their own serious problems, which in the eyes of the post-Mao leaders made some elements of capitalist urbanism seem not so bad after all. So while there may not be invariant features of urbanism, there may be universal tradeoffs that have to be faced. Efforts to avoid one set of problems may engender a different set, and in the end planners and political leaders are left trying to decide which combination of institutional virtues and defects they are best able to live with. Can a system that can eliminate prostitution avoid political persecution? Can world-quality science be fostered without at the same time creating a high degrec of inequality? The situation in China in the early 1980s was still in flux, and the eventual formula for dealing with these dilemmas of urbanism was still under debate.

\section{REFERENCES}

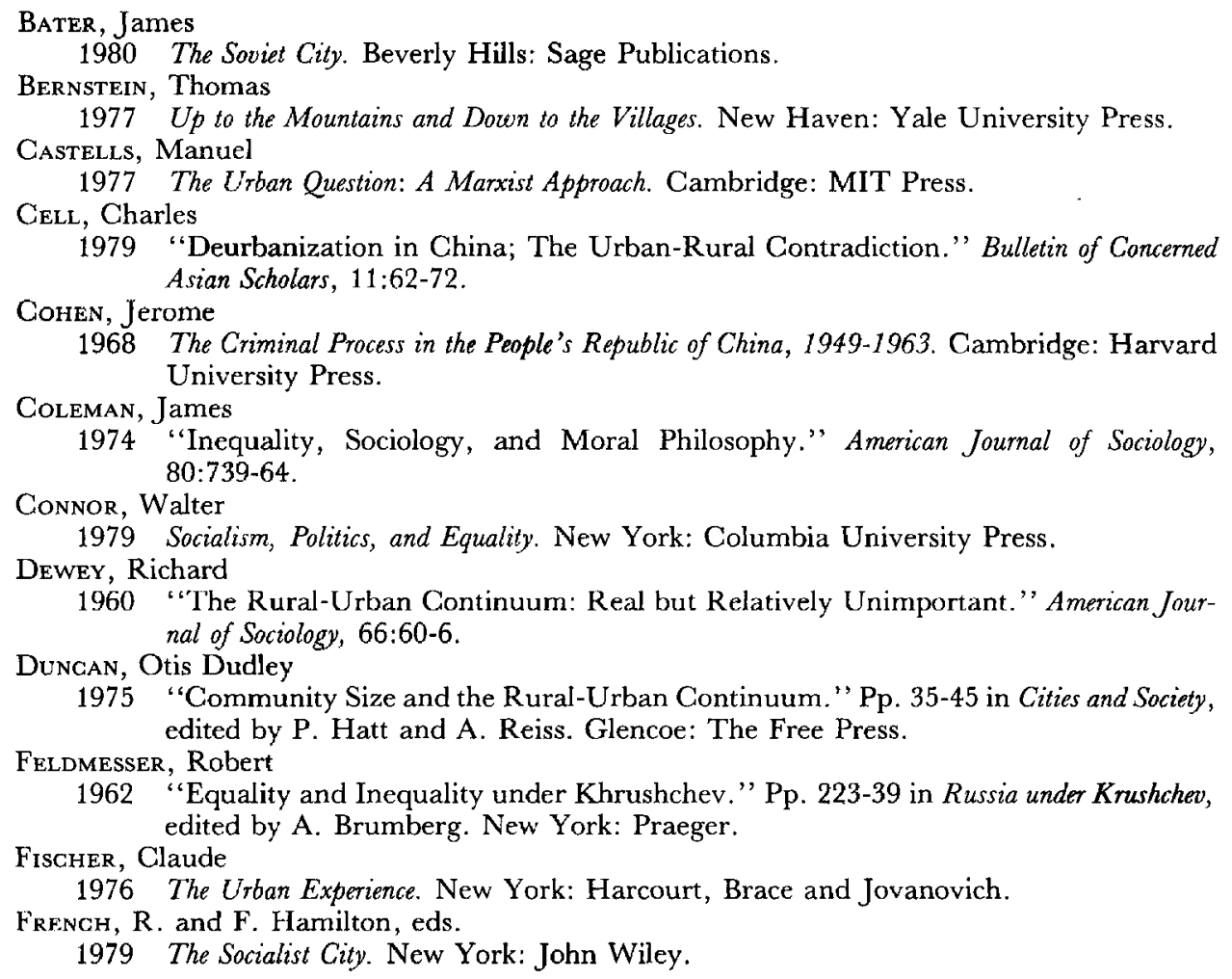


Howe, Christopher

1981 'Industrialization under Conditions of Long-run Population Stability: Shanghai's Achievement and Prospect." Pp. 153-87 in Shanghai: Revolution and Development in an Asian Metropolis, edited by C. Howe. Cambridge: Cambridge University Press.

Konrad, Gyorgy and Ivan Szelenyi

1974 "Social Conflicts of Underurbanization." Pp. 206-26 in Urban and Social Economics in Market and Planned Economies, Vol. 1, edited by A. Brown, et. al. New York: Praeger.

Korzec, Michael and Martin King Whyte

1981 'Reading Notes: The Chinese Wage System." China Quarterly, no. 86:248-73.

LinDBLOM, Charles

1977 Politics and Markets. New York: Basic Books.

Meisner, Maurice

1974 "Utopian Socialist Themes in Maoism."' Pp. 207-52 in Peasant Rebellion and Communist Revolution in Asia, edited by J. Lewis. Stanford: Stanford University Press.

MOORE, Barrington

1950 Soviet Politics: The Dilemma of Power. Cambridge: Harvard University Press.

MuRPHEY, Rhoads

1980 The Fading of the Maoist Vision. New York: Methuen.

OFer, Gur

1976 "Industrial Structure, Urbanization, and the Growth Strategy of Socialist Coun-

Okun, Arthur tries." Quarterly Journal of Economics, 90:219-44.

1975 Equality versus Efficiency: The Big Tradeoff. Washington: The Brookings Institution.

OrLeans, Leo

1982 "China's Urban Population: Concepts, Conglomerations, and Concerns." Pp. 268-302 in China under the Four Modernizations, Part I, edited by J. Hardt. Washington: U.S. Government Printing Office.

SideL, Ruth

1974 Families of Fengsheng. Baltimore: Penguin.

Sмітн, Michael

1979 The City and Social Theory. New York: St. Martin's Press.

STINCHCOMBE, Arthur

1959 "Social Structure and Organizations." Pp. 142-93 in Handbook of Organizations, edited by J. March. Chicago: Rand McNally.

Szelenyi, Ivan

1978 "Social Inequalities in State Socialist Redistributive Economies." International Journal of Comparative Sociology, 19:63-87.

1981 "Urban Development and Regional Management in Eastern Europe." Theory and Society, 10: 169-205.

Tien, H. Yuan

1973 China's Population Struggle. Columbus: Ohio State University Press.

WALDER, Andrew

1981 "Work and Authority in Chinese Industry: State Socialism and the Institutional Culture of Dependency." Unpublished PhD dissertation, University of Michigan.

1982 "Some Ironies of the Maoist Legacy in Industry." Pp. 215-37 in The Transition to Socialism in China, edited by M. Selden and V. Lippit. Armonk: M. E. Sharpe.

WANG Yalin and Li JinRONG

1982 "Chengshi Zhigong Jiawu Laodong Yanjiu." (Research on the domestic chores of urban workers and employees) Zhongguo Shehui Kexue, no. 1:177-90.

White, Lynn

1977 "Deviance, Modernization, Rations and Household Registers in Urban China." Pp. 151-72 in Deviance and Social Control in Chinese Society, edited by A. Wilson, et. al. New York: Praeger.

WhYTe, Martin King

1973 "Bureaucracy and Modernization in China: The Maoist Critique." American Sociological Review, 38:149-63. 
1981 "Destratification and Restratification in China." Pp. 309-36 in Social Inequality: Comparative and Developmental Approaches, edited by G. Berreman. New York: Academic Press.

WhYTE, Marting King and William Parish

1983 Urban Life in Contemporary China. Chicago: University of Chicago Press.

WIRTH, Louis

1938 "Urbanism as a Way of Life." American Joumal of Sociology. 44:3-24.

Yanowitch, Murray and Wesley Fisher, eds.

1973 Social Stratification and Mobility in the USSR. White Plains: International Arts and Sciences Press.

Zhongguo Jingïi Nianjian

1981 (Chinese Economic Yearbook) Peking: Economic Management Journal Press.

ZHou Jin

1979 “Housing China's 900 Million People." Beijing Review, no. 48:18.

\section{NOTES}

1 Much of the data used to make specific comparisons comes from interviews conducted jointly with William Parish in Hong Kong in 1977-78 with 133 former residents of cities in China. In particular, we will utilize data on a sample of households of neighbors who lived near our informants, and on a weighted neighbor household sample that is designed to compensate for the mismatch between the urban places from which our informants came and the distribution of urban places by size in China. For details on the specifics of our methods, how data derived from our sample compare with official Chinese statistics, and how we have dealt with various problems of bias in our interviews, consult the methodological appendices in our forthcoming volume, Urban Life in Contemporary China, (1983). Many of the issues discussed in this paper are treated in greater detail in that same volume.

2 There is a system of hiring temporary workers for construction or other physical labor jobs around the enterprise that doesn't have to go through the labor bureaus, but these low status jobs are a minor part of the employment system and do not constitute an attractive alternative for those already in state employment. In subsequent paragraphs there are similar minor exceptions to some of the general patterns I discuss, but I would argue that these do not contradict the overall contours of the institutional system.

3 About $20 \%$ of non-agricultural employment in China involves work in "collective" rather than state enterprises. Collective enterprises are often relatively small workshops and service facilities that are not on the state budget, and which are responsible for their own profits and losses. Employees in some well-endowed collective enterprises receive fringe benefits that are similar in range to those enjoyed by employees in state firms, but in other collective enterprises they receive much less, or even nothing at all besides their wages.

4 This figure is misleading in one respect. It ignores the fact that significant portions of the urban population may be sent to live in the countryside for a period, and then allowed to return later. Such temporary moves were ignored in this computation. There are also no good comparative statistics, or figures on China before 1949 , to compare this figure with, although it obviously contrasts with the often-cited figure that the average American family moves once every five years. For details on an attempted comparison with India, which shows more mobility of the urban population there than in China, see Whyte and Parish 1983, Chap. 2.

5 I should note, however, that our urban household sample included only one person who falls in the category Chinese term "high-ranking cadre" - those of rank 13 and above in the official state cadre hierarchy. So it is entirely possible that there is a very small urban elite which would not bulk large in any general urban sample such as ours that does enjoy a particularly advantaged living standard. In other words, the small size of this specially privileged group may make Figure 1 a poor test of its existence, and the advantages of such a group might have a large impact on public opinion in spite of their small numbers. See the discussion to follow. 